\title{
Leaders and Managers Styles towards Employee Centricity: A Study of Hospitality Industry in United Arab Emirates
}

\author{
Kristelle Marjori Matira ${ }^{1}$, Olawumi D. Awolusi ${ }^{2}$ \\ ${ }^{1}$ University of Roehampton, London, UK \\ ${ }^{2}$ Kampala International University, Kampala, Uganda \\ kristelle.matira@roehampton-online.ac.uk, awolusi.olawumi@kiu.ac.ug
}

\begin{abstract}
Different styles of leadership have emerged within different studies and have been proven in different ways throughout the years. Consequently, the aim of this study was to identify the effect of leadership styles towards employee centricity within the Hospitality Industry in United Arab Emirates (UAE). The study's conceptualization was derived from Burns (1978) theory on circulating the influences, inspirations, motivations, encouragements and consideration where behaviors such empathy, optimism, enthusiasm and openness are nurtured. Multiple regression analysis was applied to understand the influence of the analytical variables and target variable (employee centricity). In total, 172 responses from different hotels within United Arab Emirate (UAE) was collected using survey questionnaires assigned to employees and 8 Managers were put through an hour interview guide questioning. Mixed method then was used to validate attributes from different parties to provide deeper insights of the given problem. Findings, based on the research data and as validated by the regression results, therefore revealed that employees, centricity greatly influenced the level of the employee satisfaction and motivation within the industry of study. Lack of trust, respect, engagement and motivation soars the big picture. Due to different aspect of responsibilities leaders and managers are entitled with, not every employee is given the proper attention and leniency over their issues. The research concluded that managers and leaders are great influence to employees which builds employee centricity as a whole. This study, therefore contributes to existing knowledge through the validation of the construed theoretical and conceptual frameworks. Consequently, employee centricity has to consider a bigger factor reclined from different characteristics of a manager's responsibilities, relationship and provisions. This is found out to incorporate different factors, like purpose and autonomy, rewards, recognition, development and growth that may encourage employees to work effectively and efficiently.
\end{abstract}

Keywords: Leaders and Managers Styles; Employee Centricity; Hospitality Industry; multiple regression analysis; United Arab Emirates.

\section{Introduction}

Most literature argued on employee centricity elevating a high performance working environment through motivation and reward system (Raducan, 2015; Fiaz, et al., 2017). Evidently, leaders are bound to acclimatize their leadership style and strategies towards an individual analysis of the surroundings to better cope up with the work setting (Fiaz, et al., 2017; Freeman \& Auster, 2011; Algahtani, et al., 2014). Managers or Employees alike are after a balanced work and personal life (Fiaz, et al., 2017; Aitken, et al., 2006) to minimize the high stress on creating high-performance working environment. The same reason has created huge expectations between management and organization impacting immensely the employees. It has been explored that Managers competency makes handling people positive while incorporating thoughtfulness and connections are rather important details in reference to Leadership and Management (Oladejo \& Awolusi, 2018; Eze \& Awolusi, 2018; Raducan, 2015; Drago, 2015). This apparently is connected to conceptualizing the best fit environment.

United Arab Emirates (UAE) becomes one of the sought tourism destinations in the world over a fast phase dynamic change. Worldwide known for their high standard hotel services and different innovative ideas of attraction as like The Palm Island, topped by Atlantis, The Palm on the crescent; Burj Al Arab known to be the world's 7-star hotel with high-end and elite guest's all year round; let's also not forget the highest peak manmade architecture, Burj Khalifa with Armani Hotel within the sophisticated setting. Pristine beaches, golden sand, sunny weather and rich culture has added the country's total charm among travellers. The proximity to different countries has also added the popularity in consolation for maintaining the top two biggest flight carriers within the globe, Emirates \& Etihad Airlines. From all these ascends the one of the most 
demanding careers across all fields and countries; Hospitality. Considering 24/7 operational demands among different guests from all around.

The world; time differences on certain locations and areas to the host cities. High competition over the market, great deal on facilities, promotions and advertisements; high expectations over the services and products, and more to mention. Each department plays very huge importance on every successful stay of a guest towards their satisfactions. Whilst each section is greatly involved in creating a memorable service. It is indeed a huge responsibility for Leaders/Managers to accomplish certain expectations. Justification of actions, decision makings, resolutions and initiatives are to be delivered on different occasions, scenarios and set of people. Managers are driven by restrictions and targets set by business environment, pressures, demands, politics, etc., submissive of their personal issues. Beyond that, the changes into a more advance complexity of today's living are another challenge arising (Fiaz, et al., 2017; Macleod \& Clarke, 2009: 66). Employees in the hotels entrust more their direct Managers far better than any other person in the organization. With the high demands, most manager close their eyes on understanding the employees needs and concerns. Even sometimes, leaders and managers do not pay attention on the real problems. Passing blame, overworked staffs, unfair and unbiased treatment, compulsory overtime and cancelled day offs are only few of what junior hoteliers face year round. This is where building rapport and communication with colleagues are very evident and much needed to break the intrigue (Fiaz, et al., 2017; Lather \& Jain, 2015).

Problem Proposition: Many of the literature on Leadership and employee centricity were based on bank (Asrar-ul-haq \& Kuchinke, 2016), construction (Jung, et al., 2016) and education (Doh, 2003) in which the authors opts to fill gaps in literature and promote further study about Leadership and Managerial constrains in hospitality industry. However, the present study is positioned to reflect on Lather and Jain (2015) review of employee engagement in hospitality industry. However employees eventually become disappointed on Manager's account when their decisions are not addressed properly. Commotion prevails when disorganization and clashes on perspective arises between managers and employees proven in many scenarios (Fiaz, et al., 2017; Foote \& Robinson, 1999). The study (Lather and Jain (2015)) depicts the importance of Leaders and Manager in the context of employee engagement. The high demand of work is required from hoteliers making them strained due to heavy workloads of day to day task; validating the fact that employee centricity is much needed to be promoted on every aspect of managerial rapport. Hence to note that since Millennials are looking for happy-life-work balance confirmed in most of the leadership literature (Fiaz, et al., 2017; Aitken, et al., 2006), the evolution encompasses the high working-performance environment towards the relationship and prospect of the employees.

Where it is understand the role of the organization is vital to drive the enthusiasm of employee centricity (Asrar-ul-haq \& Kuchinke; 2016). The study is designed to promote the factor of Employee Centricity within the Hotel Industry through Leaders and Managers. Understanding the world of Hospitality entails more experience and exposure to the real world of the operations in hotels. What we intend to understand in this study is to learn how Leaders/Managers within hospitality industry carry out their responsibilities towards their respective employees or subordinates which delivers the maximum efforts on completing the job well done for their customers. The validated facts that Manager are huge impact towards their employees and not alone organization's responsibility will definitely help hotels and same entities within as like restaurants, spas, fitness centers, etc. to identify what lacks on motivational aspirations among managers and what employees are expecting from their leaders/managers within the hospitality industry. Transcending from the Transformational and Servant Leadership (Fiaz, et al., 2017; Algahtani,; 2014), the study aims to help on presenting a valuable research in hospitality industry based in UAE which can change the minds of current leaders and manager; more so to guide emerging managers on how to promote employee first policy beyond high demand operational activities.

Objective of the Study: The study main objective is to identify the effect of leaders/ managers' leadership styles towards employee centricity within Hospitality Industry in the UAE. Also to note are the specific objectives that revolve around the six (6) independent variables:

- To gain clear facts on the influence of leaders/ manager daily interaction with employees on employee centricity. 
- To check how employees perceives the influence of their relationships with their leaders and managers on employee centricity.

- To identify the influence of employees expectation from their leaders and managers on employee centricity.

- To check the influence of the leaders and manager's daily responsibilities on employee centricity.

- To identify how managers building rapports with employees influences employee centricity.

- To understand the effect of leaders and managers provisions to the employees on employee centricity.

Based on the above objectives, the following are the research questions, concise to be given importance within the content of the study:

- What is the influence of leaders and manager daily interaction with employees on employee centricity?

- What do employees think is the influence of their relationships with their leaders and managers on employee centricity?

- What are the influences of employee's expectation from their leaders and managers on employee centricity?

- What are the influences of leaders and manager's daily responsibilities on employee centricity?

- How can managers and leaders building rapports with employees' influences employee centricity?

- What is the effect of leaders and managers provisions to employees on employee centricity?

The study is therefore, motivated and positioned as a veritable way of understanding further leadership and management context, its approach and the purposes is a gateway to explore what is expected of them and how they can influence their subordinates better. What's more important is to know the behavior of Leaders/Managers who play major part on their employee's day-to-day tasks (Raducan, 2015; Fiaz, et al., 2017) to capture and create potential actions for high spirits and mutual commitments (Antoni, et al., 2017; Ganesh, 2016; Fiaz, et al., 2017; Lather \& Jain, 2015; Noria, et al., 2008) between management and subordinate producing imminent result beneficial to the working environment (Antoni, et al., 2017; Ganesh, 2016). The influence of leaders or even manager is within the power of their actions and words promoting their legacy throughout the people they can make the differences (Palmer, 2017). Furthermore, the study emphasizes different values of leaders and managers to support the arguments of how they leverage employee centricity despite the huge plea on business setting.

\section{Review of Relevant Literature}

The value of leaders/managers within the organization setting is emphasized in this study. This is an attempt to further guide all managers on reflecting the same to employee-manager relationship. The evidence is oriented to the Hospitality Industry where employees are referred to as the juniors or any staff reporting to a senior. The study also address leaders as the seniors accountable to juniors as like team leaders, shift leaders, supervisors and the same account; a bit different to most definition of leaders in leadership articles or journals referring to as an individual with great influence and motivational approach over a long term goal (Kesting, et al., 2016; Fiaz, et al., 2017). This definition is derived from the setting of hotels where supervisors are referred to as leaders while Managers are those who are already appointed as Managers. On the other hand, employee centricity is also define as the aspiration of organization to motivate and influence employees to the betterment of their general concerns, well-being and work interest (Fiaz, et al., 2017; Raducan, 2015; Algahtani, 2014). This study reflects Fiaz, Su, Ikram, and Saqib (2017) who posits that leadership exhibited by managers often contribute to the valued outcome of organizational objectives. Moreover, the expectation was to promote employee centricity through the leaders/managers within the Hospitality Industry concentrated in United Arab Emirates.

Conceptual Framework: The framework below (Figure 1) shows collaboration of employees and leaders/managers dedication towards employee centricity. The motion directs parties, employees' and managers alike are believed liable for achieving employee centricity stressing the importance of organization's initiatives that plays as a driving force for building the connection (Lather \& Jain, 2015; Asrar- 
ul-haq \& Kuchinke, 2016). Looking at the hoteliers' daily routines composed of nine (9) hours per day at work and extendable; we proposed the contribution of the six (6) independent variables within the theoretical framework of this study.

\section{Figure 1: Conceptual Framework of the Study}

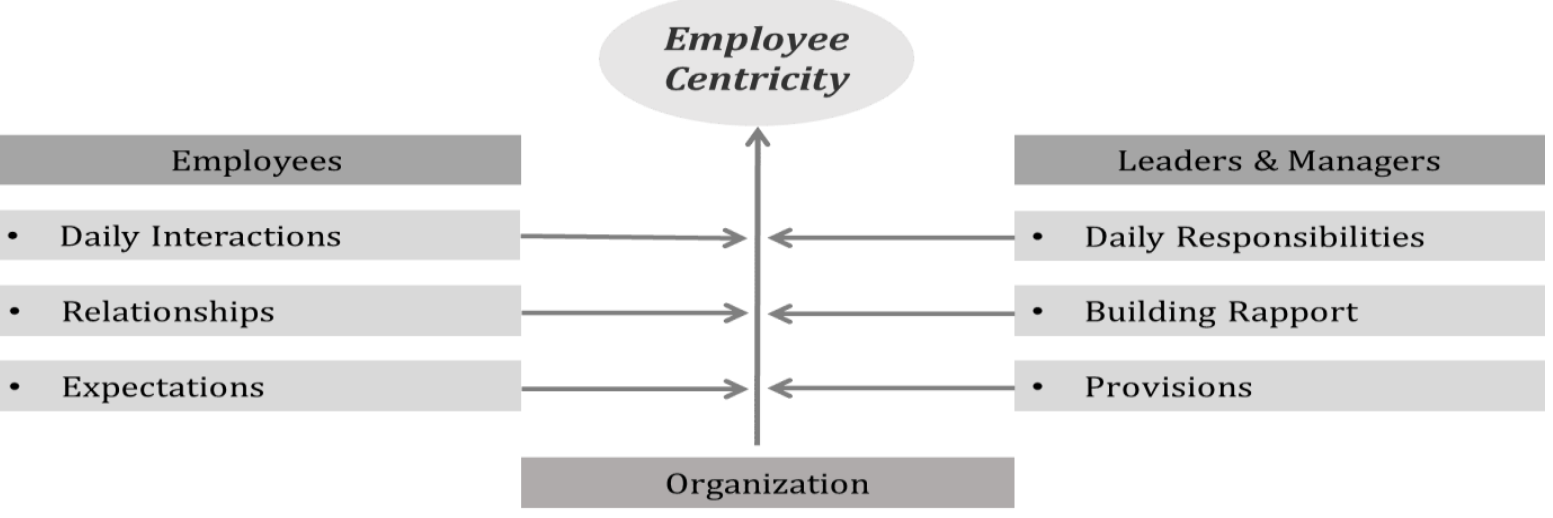

Employee Centricity in an Organization Setting: Organization drives the initiatives on fulfilling the necessities to match the expectation and provides strong healthy environment to the employees (Fiaz, et al., 2017; Shek, et al., 2015). This also demands the leaders and managers to promote same efforts to meet one goal, whilst leaders and managers are expected to radiate roles into different perspective to cope with the demands from internal and external influences. Employee Centricity is defined as the focused on nurturing human well-being and primary necessities (Fiaz, et al., 2017; Raducan, 2015; Algahtani, 2014) for employees within an organization. Motivation and satisfaction takes part in which supports the working environment. Motivation is defined as the involvement of individuals towards the organization's initiatives (Ganesh, 2016; Shanks, 2017) while satisfaction is referred as the fulfillment of rewards gained from past experience (Ganesh, 2016). Therefore, it is conceptualized that the efforts from employees and managers are in the same construct. The conceptual framework therefore suggests six (6) independent variables which connect the two (2) subjects of the study, leaders/managers and employees. Specifically, managers and employees are expected to play veritable roles on the composition of employee centricity by understanding the day to day attributes of both parties.

Daily interaction is guided instructions to employees expected to help on performing their duties. This added the whole set of responsibility from the employees as what is to perform (Fiaz, et al., 2017; Ganesh, 2017; Algahtani, 2014). Gupta (2015) has underpinned this as job involvement where job is central to the person's identity. Relationship is defined as connectivity between different individuals. Good relationship with the Managers is to connote a good stand point for employees to ensure they can rely on the people around them (Gupta, 2015). When individuals feel at ease with everyone in a work place, their self-motivation increased resulting to a more relaxed environment (Fiaz, et al., 2017, Mensah \& Tawiah, 2015). Expectation is defined as a strong hope that something good will happen. While encouraging participation, motivation increases therefore building expectations as a result of an exchange (Gupta, 2015; Mensah \& Tawiah, 2015). Employees' belongingness and connection to the organization through their managers are very important in promoting employee directions (Lather \& Jain, 2015). On the other hand, the most important aspect of building leadership is through understanding their role in the equation as leaders and managers (Algahtani; 2014; Fiaz, et al., 2017; Raducan, 2015).

Leaders must direct their motives on creating Clarity, Connectivity, Authority, Capability and Competency (Lather \& Jain, 2015). Daily responsibilities are one of the necessities from employees' daily interactions. Daily responsibilities pertain to the daily task that Leaders/Manager are expected to deliver and communicate in order to gain clear goals within the day-to-day activities and set goals to direct employees (Fiaz, et al., 2017; Ganesh, 2017). Building rapport is essential for manager in maintaining camaraderie within the team. The employees feel at ease on bringing their concern and speak up of their situation without any hesitation of being penalized or reprimanded promoting their real situation (Lather \& Jain, 2015). Gaan 
(2016) stressed that through positive emotion and positive concepts, job satisfaction, alienation, burnout and intention to quit is totally eliminated. Provision is defined as the achieved outcome of the expectations. This only pertains to what are the things that a manager can offer over their influence (Mensah \& Tawiah, 2015; Drago, 2015). Association between Managers and Employees' regular interaction, innate relationship and give-and-take expectations are also very important to construct bridging the connection on accomplishing employee centricity.

Theoretical and Empirical Reviews: Understanding the complexity of manager's responsibilities and tasks has also shown research on understanding the needs of employees (Shanks, 2017; Drago, 2015). It is also believed that the process is set forward to venture steps that would acknowledge the behaviors of the employees to strategize properly (Mensah \& Tawiah, 2015). For the purpose of this research, discussion was drawn to Need-Base Theory focused to resonate the drive of the employees giving bigger opportunities for managers to understand subordinates. While Servant Leadership, Transformational Leadership, Situational and Behavioral Leadership were given emphasis to demonstrate manager traits needed to address employee behaviors.

Need-Based Theory: Promulgate the needs of a certain individual accordingly which varied from one person to another (Mensah \& Tawiah, 2015). This theory is introduced by the following postulates: Maslow Hierarchy of Needs - this is one of the first theories postulated for the concept of the need-based theory. The conclusion is to complete the lowest level of need and then moving forward up to achieving the highest level (Shanks, 2017; Mensah \& Tawiah, 2015). The employer would need to understand the hierarchy of needs which the individual belongs (Mensah \& Tawiah, 2015). The improvement from lower to higher level is called satisfaction progression by Maslow (Shanks, 2017). There are five level of which dependent to an individual (Shanks, 2017; Mensah \& Tawiah, 2015): Psychological needs - needs that sustain a human being as like oxygen, food, water and sex; Safety needs - free of physical danger, including shelter, safe and healthy environment, job security, and protection against emotional dissatisfaction; Social needs - needs for social belongingness and acceptance to others and the group whilst a will for human interaction and support; Selfesteem needs- higher needs after belongingness divert to natural self-confidence and the state to produce satisfaction over prestige, status and power; Self-actualization needs- a drive to achieve what one is capable of becoming through autonomy, growth and development and maximizing full potential (Asika \& Awolusi, 2013; Awolusi, 2013a).

Alderfer's ERG Theory: This theory is conceptualize over Maslow Hierarchy of Need postulated to revolved only within three (3) factors wherein he believed that individuals are opt to move backwards or forward eliminating the follow through steps (Shanks, 2017; Mensah \& Tawiah, 2015). He called this action frustration-regression principle where individuals decide to move within levels depending on their needs (Shanks, 2017). Existence - the combination of two needs from Maslow Theory pertaining to the common necessities - psychological and safety needs; Relatedness - this pertains to the belongingness, relationship and support system; Growth - the combination of two last needs in Maslow Theory, esteem and selfactualization needs; whereby achievement and power is demanded to succeed; Herzberg's Two Factor Theory - this is another principle reclined to Maslow theory of needs, conceptualized on two model which is motivators and demotivators (also called hygiene). He acclimatized that motivators are psychological opportunities (Drago, 2015) that leads to successful feeling of achievement while demotivators are termed to which doesn't provide real achievements towards an employee needs (Drago, 2015; Asikhia \& Awolusi, 2015; Awolusi, 2013b).

McClellands Acquired Needs Theory: The idea gives emphasis on having needs throughout lifetime (Shanks, 2017). These needs are developed through time and are experienced in life (Shanks, 2017). There are three motivators within this concept: Need for Achievement - the drive to achieving goals, success and completion of tasks; Need for Power - the desire to control, take accountability and responsibility and autonomy; Need for Affiliation - the need to belong and gain relationship with others (Asikhia \& Awolusi, 2015; Awolusi, 2013a). Need-Based Theory then summarizes the needs of an individual dependent on one person to another where the intensity of desire differs. This only acclimatized that satisfaction is achieved through different aspect of life and levels of need. 
Action towards the Needs - Leadership Styles: Many have witness different leaders and influential managers making their way known to the world. The motivation across different leadership styles validated the followers desire to believe in one individual (Shek, et al., 2015). Many theories have describe the importance of leadership objectives over their desired outcome (Newman, et al., 2015). On the contrary, it is understood that Needs-Based Theory revolves into understanding of several factors of employee necessities while Leadership Styles drives the approach to which managers are entitled to act (Mensah \& Tawiah, 2015; Shanks, 2017; Drago, 2015; Fiaz, et al., 2017). This equal relationship therefore promotes motivation and satisfaction required to maintain a natural and well-balanced working environment promoting Employee Centricity. Theories conceptualizing leaders being made and not born (Shek, et al., 2015) for instance, is identified through Situational Leadership arising from a leadership that matched the environment orientation (Shek, et al., 2015; McCleskey, 2014) and while Behavioral or Trait Theory are identified leadership distinctive of the shown abilities, traits and characteristics inherited from generations (Shek, et al., 2015; McCleskey, 2014).

It is believed that both should not be identified differently as they are considered to fill in criticism entitled for each respective theory. While Situational leadership advances in the experience of a leader, Trait theory recognize the needs of subordinates wherein their behavioral responses are necessity and adapting traits promulgates on the given situation. Both are considered a handful tool for meeting subordinate needs. Servant Leadership on the other hand, is a devotion to one's followers where demonstrating selfless motives and promotes altruistic work for the tribe, country or society (Newman, et al., 2015). The satisfaction for commitment and the purpose driven generates from the interest of the leaders (Newman, et al., 2015). It is a step in balancing needs of both leaders and followers where working together is aimed in fulfilling organizational goals (Irving \& Berndt, 2017). Global measures of servant leadership (Newman, et al., 2015) have also proven the passion driven by satisfaction had come around as a fulfillment over the leaders' personal goals. Thus Transformational constituted in the same topic centered through subordinates' needs (Irving \& Berndt, 2017; Fiaz, et al., 2017; Shek, et al., 2015).

The definition positions the followers understanding of how important it is to achieve the goals (McCleskey, 2014). Burns (1978) theory of Transformational Leadership conceptualized on circulating the influences, inspirations, motivations, encouragements and consideration where behaviors such empathy, optimism, enthusiasm and openness are nurtured (Fiaz, et al., 2017; McCleskey, 2014). Therefore, workers feel their value and input to cast the achievements of the team. Challenging setting increases the belief that upon goal completion there is a huge satisfaction for one individual (Fiaz, et al., 2017). Bass (2008) though revised the concept of transformational leadership to a modernize approach in which he believes innovation, flexibility, adaptiveness and responsiveness deviating situational leadership and behavioral theory more emphasized (Shek, et al., 2015; McCleskey, 2014). This is induce towards collective goals where ethical connotations and morality is vital resulting to mutual reproduction of subordinates becoming leaders while leaders become their moral agents (Shek, et al., 2015). Consequently, it is hypothesized in this study that employee centricity can be built around the style of leadership as an influence from leaders and managers. On the other hand, it is also hypothesized that leaders and managers are effectively demonstrating employee centricity in hospitality industry within UAE to generalize the context.

Empirical evidence on leadership has made its way on discovering new ideas to figure out leadership styles. Leaders and Managers are driven by must do and what they have to do (Raducan, 2015; Algahtani, 2014), the assumption ideas are not only contributed by traits or characteristics but rather by dynamic environment essentials expected to influence personal objective, values and belief of employees within their significant needs (Raducan, 2015; Kesting et al., 2016; Jung et al., 2014; Agathani, 2014). It is learned that different styles deviates from employee needs which differs from one person to another. This goes for the saying, 'Managers do things right, while leaders do the right things'; not all managers can be leaders and not leaders are actually managers (Algahtani, 2014). As like the regression model hypothesis incorporated in Fiaz, et al. (2017) study determined that the association of employees' motivation and leadership styles are prominent. These leadership styles impact the motivation of employees in semi-government institutions in Pakistan where democratic style of leadership is more advised to be implemented. It is to note that people required participative, friendly and leaders who believed in their people (Fiaz, et al., 2017) to build a better 
team. Raducan (2015) worked on Leadership in the mirror (Raducan, 2015), a project research of different growing leaders introduced to understand more realistic approach on the most effective leading way of today.

The new concept was determined from personal observation of 50 person-subordinate in Romania which was divided into two groups (Raducan, 2015). In conclusion, new grown up leaders are better to lead than hiring managers according to leadership that they were accustomed to (Raducan, 2015). This is because the attributes from the legacy is likely to demand traditional leadership arising from different challenges on hand (Raducan, 2015). In other words, dealing with innovations of changing environment is a must for leaders to cope up with not only the generations but with the trends. On the other hand, Lather and Jain (2015) has revealed that only clarity and control makes the difference within employee engagement. Their study revealed that motivators of male and female in Hospitality Industry in India differ; therefore leaders focus should be respective to their needs (Lather \& Jain, 2015). Males are more engaged when leaders demonstrate democratic control (Lather \& Jain, 2015) while female are more concerned on career advancement aside from the importance of control. Motivational factors is believed to shapes employee's personal and professional aspect as like interpersonal, reward and satisfaction within organization subsequent to fluctuating behavior, attitude and drive with effect on productivity and performance (Fiaz, et al., 2017; Shanks, 2017; Kesting et al., 2016; Jung et al., 2014).

\section{Methodology}

The natural dynamicity of the hospitality field and developing theoretical perspective best fit Pragmatism as it consider reality to bite the meaning of truth (Venkatesh, et al., 2013). Pragmatism usually recruits mixed methods of quantitative and qualitative methods together. Consequently, the present study adopted a mixed method approach to validate attributes from different parties in an attempt to provide deeper insights of the given problem (Almpanis, 2016; Venkatesh, et al., 2013). It captured the real stance of employees and leaders/manager over employee centricity in the field of hospitality industry. While it is also to reflect on the argument of combining two different assumptions, mixed methods also finds its way to reveal facts to collaborate with the current practices (Easterby-Smith, 2012). In return, the advantage is evident on a knowledgeable and critical findings validated within the possibilities and limitations of respective research techniques (Almpanis, 2016; Venkatesh, et al., 2013).

The combination of both qualitative and quantitative study helped in analyzing employees and leaders/ managers feedbacks. The study built it's respondents from different four (4) and five (5) star rating hotels within the seven (7) Emirates of UAE. Respondents were composed of hotel employees from different departments/sections regardless of their areas of specialization and demographics. Restrictions were only applied within staff leveling. Quantitative approach involved rank and file employees using survey questionnaires to easily collect mass data (Easterby-Smith, 2012). The survey questionnaires answered the three (3) independent variables from employee perspective. In consideration with the level of education from this audience, the questionnaires were designed to quickly capture the selections from 1 to 5 ; 5 being the highest level of satisfaction and 1 to be the least level of satisfaction. Approximate 172 respondent's questionnaires were compiled for this data collection. In addition, a sit-down guided interview was adopted in the qualitative segment of the study. Specifically, the eight (8) respondents were managers with two (2) years minimum experience, and also supervise at least 2 subordinates. Discussion revolved around the 3 individual variables emulated for managers to describe employee centricity. Mixed Method employed in this study best fit the aim that understood both employee and manager's perspective.

Therefore the apprehending combination of both data promotes the genuine impact of the findings (Almpanis, 2016; Venkatesh, et al., 2013). This method is best used to address and be able to explore and confirm the research questions (Venkatesh, et al., 2013). Furthermore, mixed method research was proven with its ability to run stronger interpretations than single method (Venkatesh, et al., 2013). It offers varied reasons and greater insights of which an individual approach cannot comprehend (Venkatesh, et al., 2013). Mixed method helped on producing an unbiased result to clarify and validate reality on the questions proposed (Venkatesh, et al., 2016; Venkatesh, et al., 2013). The use of other method was also considered in this study, namely, grounded theory and ethnography. However, both grounded theory and ethnography does not corresponds with pragmatism as the paradigm of this study (Almpanis, 2016). While grounded theory 
connotes comparative result (Johnson, 2015) that carries out qualitative research aiming to inductively generate theory in research (Madhiuon, et al., 2017), ethnography on the other hand promulgate given method of inquiries on familiarity and records apprehension (Mijs, 2016). Evidently, both methods will divert the purpose and generate different facts rationalized within the given topic.

Population and Sampling: The study was conducted throughout the UAE, with participants mainly from 4 to 5-star hotels within the respective Emirates. These hotels were composed of approximately 340-400 employees. Different departments as like Rooms Division, F\&B, Finance, Recreation and Culinary participated in the survey questionnaires intended for quantitative data collection with 172 compiled surveys. Convenience sampling was acquired in this method. Considering the aim of the study is to get the mind-set of the group samples from its emirates within UAE, this technique helped in the ease of collecting samples within the hotel properties involving those who are easily accessible and willing to participate in the study (Asikhia \& Awolusi, 2015; Awolusi, 2013a; Almpanis, 2016). One-hour guided interview for quantitative data collection alternatively were set for managers which was attended by 8 particular operations manager including HR Managers, Restaurant Managers and Front Office Managers. The collection of this data is directed to purposive sampling aiming to promote specific basis rather than a random representative (Almpanis, 2016).

Sample Size Determination: As UAE positioned itself as the biggest tourism hub in Middle East, numerous hotels within the country becomes an advantage towards tourism. However the study concentrates on collecting hotel representative within UAE due to the restriction of other hotel corporate guidelines refusing researches to be held within the property. Another challenged faced during this period was the busy operation demands of the peak season from month of September - December. However, the adopted mixed method reassures integrative correspondence by keeping our research objectives intact (Asika \& Awolusi, 2013; Awolusi, 2013b; Venkatesh, et al., 2013). A sample size of 400 was determined through Taro Yamane formula from a population of 2056 employees from qualified hotels. Individual questionnaires were distributed from different sections and nationalities of rank $\mathrm{n}$ file employees for the purpose of quantitative data collection. In total, 172 questionnaires were collected and processed, as well as, 8 completed interviews.

Research Instrument Construction/ Administration: Questionnaires are created in relation to the aim of the study and created from the researcher's vision understanding the whole concept of managers and employees relationship and employee centricity. Employee Questionnaires were referenced from Professor Ganesh (2016) study where fundamental of motivation and satisfaction was derived from external and internal behaviors of an employee dependent on the direction of their leaders comprehending organizational goals. He also emphasized that motivation is an integral part of engagement essential for individual performances (Ganesh, 2016; Gaan, 2016) where satisfaction outweighs the measure of the leaders and organization's motivation (Ganesh, 2016; 102). This translated to 20 questions revolving into the three (3) individual Employee variables namely Daily Interaction, Relationship and Expectations and finally four (4) questions depicting employee centricity were construed. Daily Responsibility, Building Rapport and Provision from Manager's individual variables are reflected from Lather \& Jain (2015) conveyed as guided Interview Questionnaires. It was associated in their study that disengaged workforce cost loss of productivity (Lather \& Jain, 2015; 60). Engagement culture are learned to be influenced by leaders who helped in cascading the vision and inspire others to work hard. Two-way communication fuel the drive of the organization clearly defining leadership and engagement as the keys to productivity (Lather \& Jain, 2015).

Pilot Test, Validity and Reliability Analysis: Drafted questionnaires were given to two colleagues with the aim of validation the respective questions. Specifically, this type of pilot testing was aimed at clarifying and validates the connection of the questions towards the purpose. Based on the feedbacks, minor revisions were made towards the wordings. The questionnaire was also reviewed by the research's supervisor (face validity), whom suggested an additional section to measure employee centricity. The questionnaires were fully ready with the amendments before the distribution. All the final questions were adapted and validated from previous literature (Lather \& Jain, 2015; Ganesh, 2016; Gaan, 2016; Fiaz, et al., 2017). In addition, the survey questionnaires were also validated by respondents through encrypted signatures to ensure all answers were given on their freewill. These answers were not tampered nor influenced by inside parties, like hotel management or the researcher at any given point. The guided interview was also recorded for this 
purpose and was documented to reassure the sources. To prove reliability, an undertaking was also signed by the Managers right after the interview.

Method of Data Analysis: In total, 172 responses were collected from the sampled hotels within UAE using survey questionnaires assigned to each employee. Questionnaires were given to each property and were distributed to different sections of the hotel. Firstly, the survey questionnaire form is evaluated and converted on tables for data analysis to determine employee responses. Data was analyzed using SPSS and Excel sheet formula for statistical method. Specifically, in order to understand the aforementioned relationships, multiple regression analysis was applied to understand the predictor variables and the dependent or criterion variable (Awolusi et al., 2018). In addition, there were eight (8) managers who answered an hour interview guided questionnaire in different locations and time. The data collected were converted and analyzed through a tabulated data analysis. Excel sheet was used for this data analysis to formulate the graphs and interpret numbers that was used in the quantitative approach. As this method is qualitative by approach, the tables were filled by the notes taken on the interview and was compressed to analyzed the main idea using the qualitative process of data analysis.

We targeted HR Managers to connect the initiatives of the hotel properties with employee centricity; while we gathered factual responses from Operation Managers for the insights of the real day to day operations. Both data was then interpreted on the same platform and was discussed on the findings using tables and graphs. Strict adherence towards ethical disbursement is applied although there is no particular experiment conducted. Ethical statement ensures privacy and confidentiality clauses for respondents (Ethical Review, 2017). Neither the company nor individuals in this research are revealed without their permissions. Ethical Local Approvals signed by HR Department of each visited properties was obtained to conduct the data collection for employees. Introductory statements in reference to the study and privacy of respondents were captured and documented within the questionnaires as well (Almpanis, 2016; Hesse-Biber, 2015; Venkata, et al., 2014). All documents were kept confidentially and were disregarded only after the final validation of the research paper (Ethical Review, 2017).

\section{Results \& Discussion of Findings}

The present study was an attempt to know about the Leaders and Managers Style towards Employee Centricity with regards to daily interaction, relationships, expectations and employee centricity. As stated in the previous chapter, the researcher selected a sample of 172 respondents in the Hospitality Industry in UAE. On this representative sample, a survey questionnaire was carried out to find out the extent of leaders and managers style. Also, an interview questionnaire was used to collect data for the study. This schedule comprised of interactive discussion relating daily responsibilities, building rapport and provisions as well as close ended questions. The results obtained were put through statistical analysis presented in this chapter.

Findings: The Following findings described the demographic variables in the study.

Table 1: Descriptive Statistics for Employee Centricity

\begin{tabular}{llll}
\hline & Mean & Std. Deviation & N \\
\hline Employee Centricity & 4.1820 & .24417 & 5 \\
Daily Interaction & 4.2220 & .04266 & 5 \\
Relationships & 4.3060 & .03782 & 5 \\
Expectations & 3.9840 & .19295 & 5 \\
Daily Responsibilities & 1.9350 & .44637 & 5 \\
Building Rapport & 2.5250 & .82632 & 5 \\
Provision & 2.2150 & .24018 & 5 \\
\hline
\end{tabular}


Table 1 show the mean presented in the study with the missing value of 5 combining the 6 independent variables. Furthermore, the level of agreement of the respondents with regards to the variables between leaders/managers and employees were tested using the survey questionnaires with 5 point scale. Respondents were asked to state whether they strongly agree, agree, fair, disagree and strongly disagree to the given statements. Results obtained were tabulated, discussed and analyzed below.

Table 2: Descriptive Statistic for Employees' Level of Satisfaction

\begin{tabular}{lllllll}
\hline & Strongly Agree & Agree & Fair & Disagree & Strongly Disagree & Overall \\
\hline $\mathrm{N} \quad$ Valid & 24 & 24 & 24 & 24 & 24 & 24 \\
\multicolumn{1}{c}{ Missing } & 7 & 7 & 7 & 7 & 7 & 7 \\
Mean & 90.6250 & 42.9583 & 25.2083 & 7.8333 & 2.8333 & 4.1804 \\
Median & 93.0000 & 41.0000 & 24.0000 & 8.0000 & 2.0000 & 4.2250 \\
Mode & 95.00 & $37.00^{\mathrm{a}}$ & 20.00 & $4.00^{\mathrm{a}}$ & .00 & $4.16^{\mathrm{a}}$ \\
Std. Deviation & 14.88744 & 9.22887 & 9.76675 & 4.48831 & 3.43469 & .19448 \\
Variance & 221.636 & 85.172 & 95.389 & 20.145 & 11.797 & .038 \\
Range & 61.00 & 34.00 & 37.00 & 16.00 & 12.00 & .76 \\
Minimum & 58.00 & 28.00 & 12.00 & .00 & .00 & 3.68 \\
Maximum & 119.00 & 62.00 & 49.00 & 16.00 & 12.00 & 4.44 \\
\hline
\end{tabular}

From table 2, multiple modes exist validated from employee questionnaires which surveyed daily interaction, relationship and expectations. The smallest value is shown on the table with missing value of seven (7). Overall mean is found to be 4.1804 and standard deviation found to be 0.19448 with overall variance of 0.038 . The results analyzed show significant and reliable.

Daily Interaction: Table 3 (Appendix A: 1) presents the level of influence to the 172 respondents in the daily interactions of leaders/ managers to employees. There were 10 statements in the scale. Out of 172 respondents, 93 respondents equivalent to $54.24 \%$ strongly agree that the supervisors and managers follow through below:

- Provide clear and realistic tasks to be completed for the day,

- Performs daily briefing to update,

- Inform and catch-up with the day-to-day changes of the work demands,

- Talk to employees privately whenever performance drops down to what is expected,

- Ask for the changes of the schedule whenever needed,

- Ask help for further task and never forced to extend working hours depriving will,

- Supports initiatives,

- Promotes job well done to the team whenever employees exceed their expectations,

- Promotes the balance between work and life environment through team buildings, socialization, etc.

- And give the employees freedom to choose the best approach to the challenges they face.

Overall, promotes independence in decision making. This explains that most of the managers and supervisors within the study industry provide better support system and leadership needed by the employees. While, 44 or $25.41 \%$ also agree on the managerial and supervisory approach in the hospitality industry in UAE and 23 or $13.37 \%$ had experience fair treatment in the workplace from their supervisors and managers. However in the level of disagreement, 7 or $4.19 \%$ disagree and 4 or $0.23 \%$ strongly disagree on the daily interactions they had experienced with their immediate heads. The figure shows that there are managers and supervisors who are supporting employees with proper guidance. This is where manager and leaders should analyze the needs of the employees to be able to support them accordingly (Shanks, 2017; Mensah \& Tawiah, 2015). Workers feel their value and input when they can contribute equally (Mensah \& Tawiah, 2015). Challenging 
setting increases the belief that upon goal completion there is a huge satisfaction for one individual (Fiaz, et Al., 2017) demonstrating their thorough engagement and motivation.

Relationships: Table 4 (Appendix A: 2) presents the level of relationship established by leaders and managers with the employees. There were 5 statements in the scale. $28.90 \%$ of the 172 respondents strongly agree on the relationship established by the managers and supervisors to their employees. 108 of the employees strongly agreed that managers never took advantage using the position to do things beyond the employees duty, 104 revealed that managers talked to them in a sensible manner, 99 answered that managers and leaders coached and mentored the employees, 95 employees strongly agreed that their leaders are approachable in personal and professional dealings while only 91 of the respondents revealed on the issues of biased. According to Gupta (2015), good relationship with the managers is to connote a good stand point for employees to ensure they can rely on the people around them. When individuals feel people around them are good, their self-motivation increased resulting to a more relaxed environment (Shanks, 2017). On the other hand, there is 2.56 level of disagreement when it comes to the relationship between and among employees and managers. $1.40 \%$ disagrees and $1.16 \%$ strongly disagrees. The results shows that there are managers who are taking advantage, rude, not giving technical assistance, unapproachable and promote favoritism inside the industry. Moreover, the results suggest that there should be interventions and other programs to address this kind of working relationships.

Expectations: Table 5 (Appendix A: 3) presents the level of employee's expectations over their leaders and managers. There were 5 statements in the scale. The total of $22.50 \%$ of 172 respondents strongly agrees on the level of employees' expectations over their leaders and managers. The level shows that 95 of the employees commend the work of their managers in the industry, 88 of them believes that managers are role models, 74 dreamt to be like their managers, 72 looked up high to the professional aspects of the leaders while only 58 of them wanted to pattern their way of life or personal matters as soon as they reached the position. Also, $13.26 \%$ agree and $8.20 \%$ fair on the issues presented. While, $3.72 \%$ disagree and $2.09 \%$ strongly disagree on the statements answered. It is notable from the table that the employees also looked or observed the personal matters of their superior and expected them to become role models not only on professional aspects but also in the personal way of carrying themselves outside the company or industry based on the number of employees (16 and 12) for disagree and strongly disagree. Moreover, expectations hold the hope of some reward in exchange of the efforts done. Naturally when a job is rightfully done, motivation grows towards employee therefore building expectations (Gupta, 2015). Employees' belongingness and connection to the organization through their managers are very important in promoting employee directions (Lather \& Jain, 2015).

\section{Qualitative Analysis}

Daily Responsibilities: Appendix B: 1 presents the level of influences of leaders and managers to employees' daily responsibilities. The respondents were asked to answer guided questionnaires presented by the researcher. The responses obtained were transcribed, tabulated and analyzed. 8 respondents were asked regarding their responsibilities inside the company or industry as managers and leaders. From the answer provided, it is concluded that they saw to it that they supervised the recruitment and promotion, rewards and recognitions, benefits and incentives, performance management as well as open door policy or the shared leadership in an organization. The responses gathered revealed that the managers and leaders take the full responsibility in order for them to run the industry, not only to please the customers but also to enhance the capability of the employees through motivation such as rewards, recognition, benefits and incentives that will boosts their performance and to also give quality service to the clientele they served in everyday interactions with people. From the tabulated response of the managers and leaders, one of their responsibilities is the performance assessment and management to give their equal and fair rewards and recognitions.

Also, benefits and incentives provided an equal opportunity for every employee to work very hard and diligently towards their tasks. Appendix B: 2 also present the daily interactions and responsibilities of managers and leaders to employees. As shown in the illustration, leading, communicating, mentoring, meeting, handling conflicts and decision making are the responsibilities of the managers and leaders based on the response given during the interview. It can be gleaned in the table that the major responsibility of the 
manager in the organization is decision making and leading. For it is really the primary or major role of every head in ensuring the better flow of the employees as well as the customers they served on the daily basis. However, response also shows that mentoring and meeting is less prioritized in the industry due to the schedule of the workers. Handling day to day conflicts is also at the shoulder of the managers and leaders. Appendix B: 3 show the rapport build by the leaders and managers to the employees. The responses of the 8 participants of the study revealed that in order to build rapport with the employees, leaders should share leadership and observe governance, demonstrates honesty, provide fair or equal assignment, supervised manpower with gender sensitivity, motivate employees, and build confidence among the people in the workplace.

Moreover, to encourage them fully to work hardly, shared governance or leadership is a vital point to emphasize to build employees' confidence on assigned tasks. This is the kind of leadership that can encourage performing duties with cooperation and responsibilities. On the other hand, demotivation and broken promises may lead the team's failure in day to day task or assignment observed on the above study; therefore leaders are suggested to avoid the same. Lastly, appendix B: 4 present the responses of the 8 participants according to theme. It can be gleaned in the table that the provisions made by the managers for their employees are guidance which means giving them and treating their co-workers as a family, much of that is the fair treatment that can surely motivate them. Additionally, it was proven that care for the staff is also a necessity. Also, it is to note that annual recognition of the workers performance contributes employee motivation due to individual satisfaction or self-fulfillment (Antoni, et al., 2017). Employees look forward on the acknowledgement of the whole company and their colleagues (Antoni, et al., 2017). Furthermore, giving incentives like socialization and other employee related activities for the employees may help build relationship, establish rapport proving leaders promote and build camaraderie among the workers through their own provisions.

Employee Centricity: Table 6 (Appendix C) presents the data on employee centricity. The data reveals that centricity lies only in the middle level of the measurement scale as presented by $58.24 \%$ described as fair out of 172 respondents. As gleaned in the table, only $20.81 \%$ strongly agree on the level of happiness in working with the managers, importance given, expectations and appreciation of employee's contribution and $10.82 \%$ just agree on the statement. On the other hand, level of disagreements is $1.63 \%$ and $0.47 \%$ strongly disagree in the centricity. The small number denotes that there is still existing problems with the relationships of employees and managers within the industry. However, the positive response is obviously bigger in the data where management should look for other interventions to improve the industry's performance. As mentioned, employee centricity is defined as the organization focused on employees' importance as a human being (Fiaz, et al., 2017; Raducan, 2015; Algahtani, 2014). Therefore, the focus of the management should also improve and be diversified towards employees. Based on our responses, employee centricity refers to purpose and autonomy, rewards, recognition, development and growth that may encourage employees to work effectively and efficiently.

Multiple Regression Results: Similar to previous studies (Awolusi, 2019; Awolusi \& Atiku, 2019), the multiple regression equation (1) below was contrived to also test the following two alternative hypotheses in this study at 5 percent level of significance: $\mathrm{H} 1_{1}$ : Leaders and managers are effectively demonstrating employee centricity in hospitality industry within UAE; H12: Employee Centricity can be built around the style of leadership as an influence from leaders and managers.

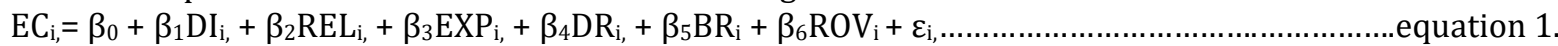

Where EC = Employee Centricity; DI = Daily interaction; REL= Relationships; EXP = Expectations; DR = Daily Responsibilities; $\mathrm{BR}=$ Building Rapport; PROV= Provisions, and $\varepsilon_{\mathrm{i}}=$ the error term. Consequently, the results of the multiple regression analysis are shown in Table 4 All the null hypotheses were rejected at 5 percent level, except on the influence of relationship on employee centricity. The overall decision was the upholding of the two alternative hypotheses. Therefore our study concludes that ( $\mathrm{H} 1_{1}$ :) Leaders and managers are effectively demonstrating employee centricity in hospitality industry within UAE. In addition, $\left(\mathrm{H} 1_{2}\right)$ Employee Centricity can be built around the style of leadership as an influence from leaders and managers. Alternatively, one-way analysis of variance (ANOVA) was also employed to test significant difference in scores on Employee Centricity across the 6 independent variables within this study. It is showed in Table 3 that regression difference scores 1 and residual difference was 3 . Relationship is the predictor variables in 
the model where it serves to be the manipulated variable in order to observe the effect on Employee Centricity. Consequently, the alternative hypothesis was accepted, while the null hypothesis rejected at 5 percent level of significance (Gupta, 2015; Gaan, 2016; Mensah \& Tawiah, 2015).

Table 3: One-way Analysis of Variance (ANOVA a)

\begin{tabular}{llllll}
\hline Model & Sum of Squares & DF & Mean Square & F & Sig. \\
\hline \multicolumn{1}{l}{ Regression } & .227 & 1 & .227 & 61.161 & $.084^{\mathrm{b}}$ \\
1 Residual & .011 & 3 & .004 & & \\
\multicolumn{1}{l}{ Total } & .238 & 4 & & &
\end{tabular}

a. Dependent Variable: Employee Centricity; Predictors in the Model: (Constant), Relationships

Table 4 shows the excluded variables collinearity statistics where the significance is between .088 and .302 . While overall it is understood that the significance on the overall scores are evident across all aspect of independent variables. It is also found that there are few factors that are directly affecting employee centricity and should also be the constant focus within the context.

Table 4: Excluded Variables

\begin{tabular}{|c|c|c|c|c|c|c|}
\hline Model & Beta In & & Sig. & Partial Correlation & $\begin{array}{l}\text { Collinearity Statistics } \\
\text { Tolerance }\end{array}$ & Decision \\
\hline Daily Interaction & $.215^{\mathrm{b}}$ & 1.881 & .201 & .799 & .646 & Significant \\
\hline Relationship & -6.304 & -7.821 & .004 & -.976 & .909 & Insignificant \\
\hline Expectations & $.205^{b}$ & 3.010 & .095 & .905 & .909 & Significant \\
\hline${ }^{1}$ Daily Responsibilities & $.297^{b}$ & 3.137 & .088 & .912 & .439 & Significant \\
\hline Building Rapport & $-.466^{b}$ & -1.379 & .302 & -.698 & .105 & Significant \\
\hline Provision & $-.178^{b}$ & -2.057 & .176 & -.824 & .999 & Significant \\
\hline
\end{tabular}

\section{Discussion of Findings}

This study emphasized employee perspective in which daily interaction, relationship and expectations are the contentment of employee necessities. Results showed that daily interaction, relationship and expectations are essential part of day to day routines of employees embraced through manager and leaders promulgating the obligatory activities on hand. Managers and leaders should analyze and recognize the needs in order to equally distribute the attention required by different individuals (Shanks, 2017; Mensah \& Tawiah, 2015; Fiaz, et al., 2017; Lather \& Jain, 2017). Accountability, motivation and engagement increases when challenge arises from job satisfaction (Shanks, 2017; Lather \& Jain, 2017). It is also to note that these 3 independent variables are a huge importance to an individual well-being. When one feels the security over their interaction, relationship and expectations among the people around them not only pertaining to the manager and leaders but to co-workers as a whole, employees feel the huge satisfaction towards keeping the job (Gupta, 2015; Gaan, 2016; Mensah \& Tawiah, 2015). The study posits that the adoption of different styles of leadership by leaders and manager should take into consideration the motivational factors of workers. Influences, inspiration and most highlighted motivations are considerably enticing in the concept but to conceptualize the style in leadership is to learn what people needs and want.

Managers and leaders are expected to nurture engagement from employees therefore it is viewed that relationship should acclimatize the orientation of managers and leaders. Consequently, similar to previous literature, it is important to know what motivates and demotivates employees as dictated by Herzberg's Two Factor Theory (Shanks, 2017; Mensah \& Tawiah, 2015; Drago, 2015). Findings also acknowledge both Alderfer's ERG Theory (that different movement is not only limited to the levels of needs) and McClellands Acquired Needs Theory by support the research on understanding the needs acquired through experiences of lifetime (Mensah \& Tawiah, 2015; Drago, 2015). Employee motives depend on their respective desires 
through time and experiences (Shanks, 2017). The combination of the 3 postulates for Need-Based Theory correlates the entire concept of the motivation intended for managers and leaders to learn and master. For example, previous empirical reviews also highlighted leadership style from Raducan's (2015) study that managers are expected to embrace changes which will suffice the need of the employees.

If expectations aren't meet the needed aspirations of our workers is not provided. However, findings contradict Maslow Hierarchy of Need (Shanks, 2017; Mensah \& Tawiah, 2015). The levels of needs are proved to differ from one person to another; hence, desires are deem to be dependent on an individual's perspective, experiences and life aspirations (Gupta, 2015; Gaan, 2016). In all, the present study revolved around motivational theories to fathom the needs of which drives workers, and leadership styles to build relationship among their subordinates revealing day to day communication. Correlation between the roles of managers and employees were adequately defined and linked together to present validated data towards the dependent variable. As we believed that employees are great assets to the company, efficiency of management therefore lies on several factors (Ganesh, 2016; Gaan, 2016; Mensah \& Tawiah, 2015). Findings, therefore positioned employees to play their roles within the organization, however the role of motivation and satisfaction should be evident to them. This is where managers are to drive their purpose towards achieving one goal by linking the gap between organization and employees (Shanks, 2017; Fiaz, et al., 2017; Gaan, 2016).

\section{Conclusion \& Policy Recommendations}

This study was aimed at understanding whether leadership styles within the UAE's hospitality industry can really influence employee centricity. It was also an attempt to understand whether hospitality industry in UAE aligns with employee centricity by promoting daily attributes defined within the 6 independent variables subjected to linked employees and manager's perspective. The study's conceptualization was derived from Burns (1978) theory on circulating the influences, inspirations, motivations, encouragements and consideration where behaviors such empathy, optimism, enthusiasm and openness are nurtured. Manager's to build rapport on the other hand should encourage honesty, motivation to work well with people and promote company values, supervise fair and equal assignment to manpower, observe shared leadership and governance to employees, and also build confidence to the workplace by promoting gender sensitivity. Multiple regression analysis was applied to understand the influence of the analytical variables and target variable (employee centricity). Findings, based on the research data and as validated by the regression results, therefore revealed that employee centricity greatly influenced the level of the employee satisfaction and motivation within the industry of study.

Conclusion: The study concluded that leaders and managers are influential towards employees' interaction as they provide better support system by completing daily tasks, work demands, guidance and direction, communication, and sound decision. Good relationship between leaders/managers and employees is proved to motivate workers to perform duties religiously where Manager's positive attitude results to a positive response from the employees. On the contrary, it is proven that the employees' expectations over their leaders and managers are to become good role models in both personal and professional aspects of employees' life. Workers look up to their immediate superior and create a mind-set of becoming the same person as they are. The influences of the leaders and managers on the daily responsibilities leading, communicating, mentoring, meeting, handling conflicts and decision making are the responsibilities of the managers and leaders based on the response given during the interview. Also, it is a major responsibility of the manager in the organization to make decisions and lead the team while, mentoring and meeting is less prioritized in the industry due to the schedule of the workers. Handling day to day conflicts is also another element to emphasis. Broken promises are considered to be a vital demotivating factor affecting employee dissatisfaction and reclined productivity. Finally, manager's provision towards their responsibilities to the employees includes treating employees not only colleagues but a family as a whole.

Additionally, fair treatment towards all subordinates was also conclusive. It is to note that the care for staff is much needed to promote motivation where constant employee recognition is a key to demonstrate satisfaction among workers (Antoni, et al., 2017). Another factor to boost satisfaction can also come from social activities and group interactions among employees initiated by managers or the company. This will surely cultivate loyalty from employees which will build camaraderie and work-life balance. 
Policy Recommendations: Since, leaders and managers are influential; therefore, they should provide support system in the company by showing hands on leadership by example. They should promote shared leadership where transformational leadership and servant leadership may sound related. Leaders and managers should show positive and good relationship among employees by giving them needed respect, appreciation, trust, and confidence. The managers and leaders should not only be in the management as top level managers but they should perform as role models following ethical principles in both personal and professional aspects of their lives. Leaders and managers need to work harder in order to inspire people in the organization. They should avoid false promises and should always be honest in fulfilling the workers expectations. Equal or fair treatment is much sought within an organization or a team. The help of monthly or yearly evaluation is totally suggested to avoid unbiased rewards and recognition. It is also noted that due process and thorough investigation can assist managers and leaders on encouraging fair treatment in order to address conflicts. Shared leadership or observing governance will too help managers and leaders to demonstrate responsibility and accountability.

Promoting delegation is a much sought approach in this aspect concluded by most of the manager involved in this study. Moreover, managers and leaders should learn how to build their employees confidence through genuine care of employees' well-being and constant guidance whether personal or professional. The study also recommends focusing on enhancing internal programs as like recognition and reward system wherein social events and activities can be developed and/or initiated. This will not only promote employee motivation yet will cultivate employee work-life balance and loyalty. Teambuilding for example is a very good tool to build relationships and teamwork which greatly intend to unite the team with one another. Lastly, providing skills enhancement (Antoni, et al., 2017) through out-of-the-box task delegation and self-learning is also suggested to break the everyday routines of employees resulting to a diversified, enthusiastic and exciting approach to the employees. Reclined from different characteristics of a manager's responsibilities, relationship and provisions; the study have proven that autonomy, rewards, recognition, development and growth would essentially stress the topic (Fiaz, et al., 2017; McCleskey, 2014).

Implications and Contribution to knowledge: This study add value to previous studies on organizations, leaderships and management's academic literatures and new ideas to opens minds of many on employees expectations from their Managers. This study bridges the gap between Leaders/Managers and Employees to divulge the face of employee centricity. The study also filled previously identified gaps in relation to employee engagement (Lather \& Jain, 2015) and motivation (Shanks, 2017) by depicting how to promote true leadership principles throughout the dynamics of a manager. The study therefore, construed that Leaders and Managers are mostly responsible on creating the organization's values towards the employee commitment (Asrar-ul-haq \& Kuchinke, 2016). Consequently, by transcending from the servant and transformational leadership styles (Fiaz, et al., 2017; Algahtani, 2014), the study is adequately positioned as valuable research in the hospitality industry based in UAE which can influence current leaders and manager. The study represents a valuable research in hospitality industry based in UAE with the aim of changing the minds of current leaders and manager.

As well as, guiding emerging managers on how to promote employee first policy beyond high demand operational activities. This study has also identified the imperative of creating good relationship among employees and managers alike. This also implies that identifying the needs of employees effectively serves the purpose of tackling the right approach on motivating them. The study can impact greatly on further studies to be conducted in reference to motivation, leadership styles and employee engagement. The study is also positioned to guide emerging managers on how to promote employee first policy beyond high demand operational activities of day to day tasks. The validated result of a weak employee centricity within the industry also constitutes major contributions to theory and practice. Hence, the much sought recommendations are essential. It is understood that different perspective of people synthesized its general level of employee. Centricity evaluates different individual from one person to another thus from one organization to another. Therefore, the general outcome varied from one leader's attribute to another.

The study revolves around a generic response towards different managerial styles within the hotels in UAE. Another limitation found in this study is the relation of motivation and satisfaction towards its principles as like reward (Shanks, 2017). Motivation rotates within the need of an individual to perform a behaviour that 
leads to fulfillment (Shanks, 2017; Antoni, et al., 2017; Ganesh, 2016). However, the study mainly concentrated on the day to day factors affecting motivation and satisfaction of employees towards their respective managers. Therefore, there is urgent need for more specific cross sectional studies on the relationships between employee centricity and highlighted topics like rewards and recognition, employee engagement, and motivational theories. In addition, this study is veritable evidence on profound diligence towards Hospitality Industry within the UAE. Further study to a wider target audience can cover the entire Gulf Hospitality Industry which is not the exposure of the present study.

Acknowledgement: This paper is an extracts from a Masters (M.Sc) in Strategic Human Resource Management thesis at the University of Roehampton, London. Prof. Olawumi .D. Awolusi was the supervisor of the study.

\section{References}

Aitken, G., Marks, N., Purcell, J., Woodruffe, C. \& Worman, D. (2006). Reflections on Employee Engagement, Chartered Institute of Personnel and Development (CIPD), 1-16.

Algahtani, A. (2014). Leadership and Management Different? A Review, Journal of Management Policies and Practices, 2(3), 71-82.

Almpanis, T. (2016). Using a mixed method research design in a study investigating the Head's of Elearning perspective towards technology enhance learning, The Electronic Journal of e-Learning, 14(5), 301-311.

Antoni, C., Baeten, X., Perkins, S., Shaw, J. \& Vartiainen, M. (2017). Reward Management: Linking Employee Motivation and Organizational Performance, Journal of Personnel Psychology, 16(2), 57-60.

Asika, N. \& Awolusi, 0. D. (2013). Modeling Critical Success Factors of Business Process Re-Engineering and Business Performance of Nigerian Oil and Gas Companies, International Journal of Services and Operations Management, 15(1), 28-43.

Asikhia, U. 0. \& Awolusi, O. D. (2015). Assessment of Critical Success Factors of Business Process Reengineering in the Nigerian Oil and Gas Industry, South African Journal of Business Management, $46(2), 1-14$.

Asrar-ul-Haq, M. \& Kuchinke, K. P. (2016). Impact of leadership styles on employees' attitude towards their leader and performance: Empirical evidence from Pakistani banks, Future Business Journal, 2(1), 54-64.

Awolusi, O. D. (2013a). Effects of motivation on employees, job commitment in the Nigerian banking industry: an empirical analysis, International Journal of Business and Innovation Research, 1(3), 1-17.

Awolusi, 0. D. (2013b). The effects of total quality management on customer service management in the Nigerian banking industry: an empirical analysis, International Journal of Management and Network Economics, 3(1), 57-77.

Awolusi, O. D., Mbonigaba, J. \& Tipoy, C. K. (2018). Mineral resources endowment and economic growth in Southern African countries, International Journal of Diplomacy and Economy, 4(1), 59-79.

Awolusi, O. D. \& Atiku, O. S. (2019). Business Process Re-Engineering and Profitability in the Nigerian Oil and Gas Industry: The Mediating Influence of Operational Performance, Information Management and Business Review, 11(3), 13-26.

Awolusi, O. D. (2019). Human Capital Development and Economic Growth in BRICS Countries: Controlling for Country Differences, Journal of Economics and Behavioral Studies, 11(4), 1-17.

Bass, B. M. (2008). The Bass handbook of leadership: Theory, research, \& managerial applications, New York, NY: Free Press, Edition 4.

Burns, J. M. (1978). Leadership, New York, NY: HarperCollins

Drago, P. (2015). The ghost of Herzberg motivational Theory: Motivators and Demotivators, International Journal- Vallis Aurea, 1(1), 15-25.

Doh, J. (2003). Can Leadership Be Taught? Perspectives from Management Educators, Academy al Management Learning and Education, 2(1), 5467.

Easterby-Smith, M., Thorpe, R. \& Jackson, P. (2012). Management Research, 4th edition, London: SAGE Publications.

Ethical Review. (2017). University of Roehampton. 
Eze, T. O. \& Awolusi, O. D. (2018). Effect of Critical Factors on Expatriate Assignment Performance in the Nigerian Oil and Gas Sector, Global Journal of Interdisciplinary Social Sciences, 7(2), 6-19.

Fiaz, M., Su, Q., Ikram, I. \& Saqib, A. (2017). Leadership styles and employees' motivation: perspective from an emerging economy, The Journal of Developing Areas, 51(4), 144-156

Freeman, R. \& Auster, R. E. (2011). Values, Authenticity, and Responsible Leadership, Journal of Business Ethics, 98(1), 15-23.

Foote, D. \& Robinson, I. (1999). The Role of the Human Resources Manager: Strategist or Conscience of the Organisation? Business Ethics: A European Review, 8(2), 88-98.

Gaan, N. (2016). Universal Endorsement of Values \& Impact on Employee Engagement, the Indian Journal of Industrial Relations, 51(3), 502-515.

Ganesh, A. (2016). Understanding the Relationship between Employee Motivation and Customer Retention, XIMB Journal of Management, 13(I), 101-114.

Gupta, M. (2015). A study on employees perception towards employee engagement, GMJ, 9(1-2), 45-51.

Hesse-Biber, S. (2015). The problems and prospects in the teaching of mixed methods research, International Journal of Social Research Methodology, 18(5), 463-477.

Irving, J. A. \& Berndt, J. (2017). Leader's Purposefulness within Servant Leadership: Examining the effects of servant leadership, leader follower-focus, leader goal-orientation, and leader purposefulness in a large U.S. health organization, Administrative Science, 1-20.

Johnson, J. (2015). Qualitative sales research: an exposition of grounded theory, Journal of Personal Selling \& Sales Management, 35(3), 262-273.

Jones, S. S., Jones, O. S., Winchester, N. \& Grint, K. (2016). Putting the discourse to work: On outlining praxis of democratic leadership development, Management Learning.

Jung, Y., Jeong, M. G. \& Mills, T. (2016). Identifying the Preferred Leadership Style for Managerial Position of Construction Management, International Journal of Construct Engineering and Management, 3(2), 4756.

Kesting, P., Ulhøi, J. P., Song, L. J. \& Niu, H. (2016). The impact of leadership styles on innovation-a review, Journal of Innovation Management, 3(4), 22-41.

Lather, A. S. \& Jain, V. K. (2015). Ten C's Leadership Practices Impacting Employee Engagement: A Study of Hotel and Tourism Industry, Vilakshan, XIMB Journal of Management 12(2), 59-74.

Macleod, D. \& Clarke, N. (2009). Engaging for success: enhancing performance through employee engagement, Department for Business, Innovation and Skills, 1-125.

Madhiuon, R., Masoumi, D. \& Farasatkhah, M. (2017). Quality Improvement in Virtual Higher Education: A grounded theory approach, Turkish Online Journal Distance Education, 18(1), 111-131.

McCleskey, J. A. (2014). Situational, Transformational and Transactional Leadership and Leadership Development, Journal of Business Studies Quarterly, 5(4), 117-129.

Mensah, E. K. \& Tawiah, K. A. (2015). Employee Motivation and Work Performance: A Comparative Study of Mining Companies in Ghana, Journal of Industrial Engineering and Management, 3(2), 255-309.

Mijs, J. (2016). The Missing Organizational Dimension of Prisoner Reentry: An Ethnography of the Road to reentry at a Nonprofit Service Provider, Sociological Forum, 31(2), 291-309.

Newman, A., Schwarz, G., Cooper, B. \& Sendjaya, S. (2015). How Servant Leadership Influences Organizational Citizenship Behavior: The Roles of LMX, Empowerment and Proactive Personality, Faculty Publications, 1-41.

Noria, N., Groyesberg, B. \& Lee, L. E. (2008). Employee Motivation A Powerful New Model, Harvard Business Review, 1-8.

Oladejo, M. J. \& Awolusi, O. D. (2018). Effect of Work-Family Role Conflicts on Employees Commitment and Organisational Performance: A study of AKLAD Interlink concept, Nigeria, Global Journal of Commerce and Management Perspective, 7(2), 81-96.

Palmer, T. (2017). The Power of Legacy, Production Machining, Gardner Publications, 26-27.

Raducan, R. (2015). Leaders vs. Managers, Psychology and Ongoing Development, SICAP, 23, 149-154.

Shamir, B. \& Eilam G. (2005). What's your story? A life-stories approach to authentic leadership development, 395-417.

Shanks, N. (2017). Management and Motivation - Online Version, Jones and Bartle Publication, 23-25.

Shek, D., Chung, P. \& Leung, H. (2015). How Unique is the Service Leadership Model? A Comparison with Contemporary Leadership Approaches, Int J Disabil Hum Dev, 2(1), 217-231. 
Venkatesh, V., Brown, S. \& Bala, H. (2013). Bridging the Qualitative-Quantitative Divide: Guidelines for Conducting Mixed Methods Research in Information System, MIS Quarterly, 37(1), 21-54.

Venkatesh, V., Brown, S. \& Sullivan, Y. (2016). Guidelines for Conducting Mixed-methods Research: An Extension and Illustration, Journal Association for Information System, 13(3), 435-395.

\section{Appendix A: 1}

Table 5: Level of Influence of Leaders and Manager's towards Daily Interaction

\begin{tabular}{|c|c|c|c|c|c|c|c|c|c|c|}
\hline Daily Interaction & $\begin{array}{l}\text { Strongly } \\
\text { Agree }\end{array}$ & $\%$ & Agree & $\%$ & Fa ir & $\%$ & D isagree & $\%$ & $\begin{array}{l}\text { Strongly } \\
\text { Disagree }\end{array}$ & $\%$ \\
\hline $\begin{array}{l}\text { 1. My Supervisors and M anagers provide } \\
\text { clear and realistic tasks to be completed for } \\
\text { the day. }\end{array}$ & 95 & 55.23 & 37 & 21.51 & 32 & 18.60 & 4 & 2.33 & 0 & 0.00 \\
\hline $\begin{array}{l}\text { 2. My Supervisors and } M \text { anagers can } \\
\text { understand the challenges of } m y \\
\text { responsibilities every time. }\end{array}$ & 90 & 52.33 & 50 & 29.07 & 20 & 11.63 & 8 & 4.65 & 0 & 0.00 \\
\hline $\begin{array}{l}\text { 3. My Supervisors and M anagers performs } \\
\text { daily briefing to update, inform and catch-up } \\
\text { with the day-to-day changes of our work } \\
\text { dem ands. }\end{array}$ & 98 & 56.98 & 41 & 23.84 & 25 & 14.53 & 4 & 2.33 & 0 & 0.00 \\
\hline $\begin{array}{l}\text { 4. My Supervisors and Managersensures } \\
\text { to talk to me privately whenever my } \\
\text { performancedrops dow } n \text { to what is } \\
\text { expected. }\end{array}$ & 88 & 51.16 & 56 & 32.56 & 12 & 6.98 & 8 & 4.65 & 0 & 0.00 \\
\hline $\begin{array}{l}\text { 5. My Supervisors and M anagersensures } \\
\text { to ask me for the changes of my schedule } \\
\text { wheneverneeded. }\end{array}$ & 103 & 59.88 & 45 & 26.16 & 20 & 11.63 & 0 & 0.00 & 0 & 0.00 \\
\hline $\begin{array}{l}\text { 6. My Supervisors and Managers ask my } \\
\text { help for furthertask and neverforced meto } \\
\text { extend my working hours deprived of my } \\
\text { will. }\end{array}$ & 119 & 69.19 & 29 & 16.86 & 12 & 6.98 & 8 & 4.65 & 0 & 0.00 \\
\hline $\begin{array}{l}\text { 7. My Supervisors and } M \text { anagers supports } \\
\text { my initiatives. }\end{array}$ & 91 & 52.91 & 53 & 30.81 & 12 & 6.98 & 8 & 4.65 & 0 & 0.00 \\
\hline $\begin{array}{l}\text { 8. My Supervisors and Managers promotes } \\
\text { my job well done to the team whenever I } \\
\text { exceed his expectations. }\end{array}$ & 79 & 45.93 & 53 & 30.81 & 24 & 13.95 & 12 & 6.98 & 0 & 0.00 \\
\hline $\begin{array}{l}\text { 9. My Supervisors and M anagers promotes } \\
\text { the balance between work and life } \\
\text { environment through team bu ildings, } \\
\text { socialization, etc. }\end{array}$ & 74 & 43.02 & 33 & 19.19 & 49 & 28.49 & 8 & 4.65 & 4 & 2.33 \\
\hline $\begin{array}{l}\text { 10. My Supervisor and M anagers give the } \\
\text { employees freedom to choose the best } \\
\text { approach to the challenges we face; he/she } \\
\text { promotes independence in decision making. }\end{array}$ & 96 & 55.81 & 40 & 23.26 & 24 & 13.95 & 12 & 6.98 & 0 & 0.00 \\
\hline TOTAL & 933 & 54.24 & 437 & 25.41 & 230 & 13.37 & 72 & 4.19 & 4 & 0.23 \\
\hline
\end{tabular}




\section{Appendix A: 2}

Table 6: Level of Relationship Established by Leaders and Managers with the Employees

\begin{tabular}{|c|c|c|c|c|c|c|c|c|c|c|}
\hline Relationship & $\begin{array}{c}\text { Strongly } \\
\text { Agree } \\
\end{array}$ & $\%$ & Agree & $\%$ & Fair & $\%$ & Disagree & $\%$ & $\begin{array}{l}\text { Strongly } \\
\text { Disagree }\end{array}$ & $\%$ \\
\hline $\begin{array}{l}\text { 11. I can approach my Supervisors and } \\
\text { Managers for everything that is bothering } \\
\text { me whether it be personal or professional. }\end{array}$ & 95 & 55.23 & 40 & 23.26 & 25 & 14.53 & 12 & 6.98 & 0 & 0.00 \\
\hline $\begin{array}{l}\text { 12. My Supervisors and Managers extends } \\
\text { his/her help by coaching and mentoring } \\
\text { our professional and personal difficulties. }\end{array}$ & 99 & 57.56 & 32 & 18.60 & 37 & 21.51 & 0 & 0.00 & 4 & 2.33 \\
\hline $\begin{array}{l}\text { 13. My Supervisors and Managers talks to } \\
\text { me in a sensible way without being rude or } \\
\text { demanding even on busy operations. }\end{array}$ & 104 & 60.47 & 40 & 23.26 & 20 & 11.63 & 4 & 2.33 & 4 & 2.33 \\
\hline $\begin{array}{l}\text { 14. My Supervisor and Manager never } \\
\text { takes advantage of me; never use his/her } \\
\text { position to request, ask, pushed me to do } \\
\text { things bevond the call of mv dutv. }\end{array}$ & 108 & 62.79 & 28 & 16.28 & 24 & 13.95 & 4 & 2.33 & 8 & 4.65 \\
\hline $\begin{array}{l}\text { 15. My Supervisors and Managers gives } \\
\text { every subordinates good and fair } \\
\text { treatments and never been biased. }\end{array}$ & 91 & 52.91 & 45 & 26.16 & 28 & 16.28 & 4 & 2.33 & 4 & 2.33 \\
\hline TOTAL & 497 & 28.90 & 185 & 10.76 & 134 & 7.79 & 24 & 1.40 & 20 & 1.16 \\
\hline
\end{tabular}

Appendix A: 3

Table 7: Level of Employee's Expectations over their Leaders and Managers

\begin{tabular}{|c|c|c|c|c|c|c|c|c|c|c|}
\hline Expectations & $\begin{array}{c}\text { Strongly } \\
\text { Agree }\end{array}$ & $\%$ & Agree & $\%$ & Fair & $\%$ & Disagree & $\%$ & \begin{tabular}{|l|} 
Strongly \\
Disagree \\
\end{tabular} & $\%$ \\
\hline $\begin{array}{l}\text { 16. My Supervisors and Managers are } \\
\text { my role models towards professional } \\
\text { and personal ethics and values. }\end{array}$ & 88 & 51.16 & 44 & 25.58 & 20 & 11.63 & 16 & 9.30 & 4 & 2.33 \\
\hline $\begin{array}{l}\text { 17. My Supervisors and Managers are } \\
\text { to be commended for running the } \\
\text { section/department. }\end{array}$ & 95 & 55.23 & 37 & 21.51 & 24 & 13.95 & 8 & 4.65 & 4 & 2.33 \\
\hline $\begin{array}{l}\text { 18. I look up to my Supervisors and } \\
\text { Managers in every aspect of } \\
\text { professional life. }\end{array}$ & 72 & 41.86 & 48 & 27.91 & 32 & 18.60 & 12 & 6.98 & 8 & 4.65 \\
\hline $\begin{array}{l}\text { 19. I look up to my Supervisors and } \\
\text { Managers in every aspect of personal } \\
\text { life. }\end{array}$ & 58 & 33.72 & 41 & 23.84 & 45 & 26.16 & 16 & 9.30 & 12 & 6.98 \\
\hline $\begin{array}{l}\text { 20. I wanted to be like my Supervisor } \\
\text { and Managers once I reached the same } \\
\text { level. }\end{array}$ & 74 & 43.02 & 58 & 33.72 & 20 & 11.63 & 12 & 6.98 & 8 & 4.65 \\
\hline TOTAL & 387 & 22.50 & 228 & 13.26 & 141 & 8.20 & 64 & 3.72 & 36 & 2.09 \\
\hline
\end{tabular}




\section{Appendix B}

1: Level of Influences of Leaders and Managers to Employees Daily Responsibilities

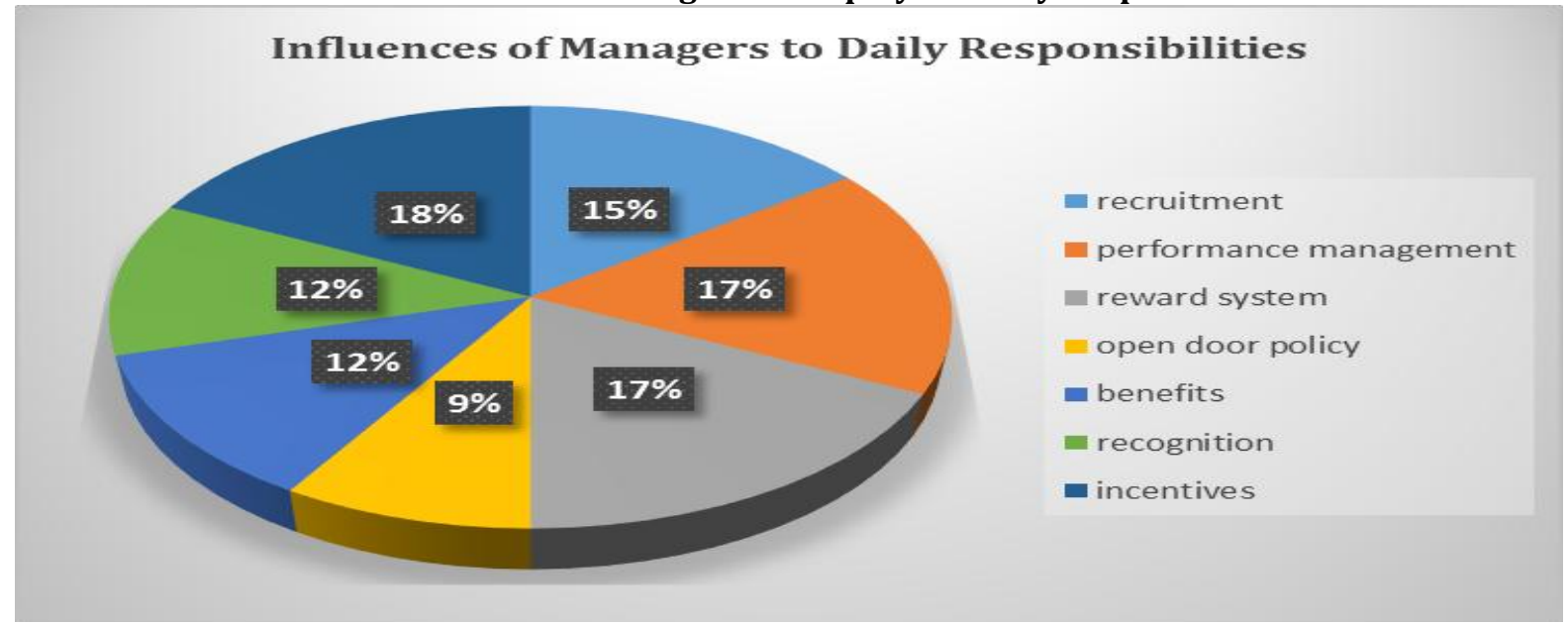

2: Daily Interactions and Responsibilities of Managers and Leaders to Employees

Daily Interactions and Responsibilities of Managers and Leaders to Employees
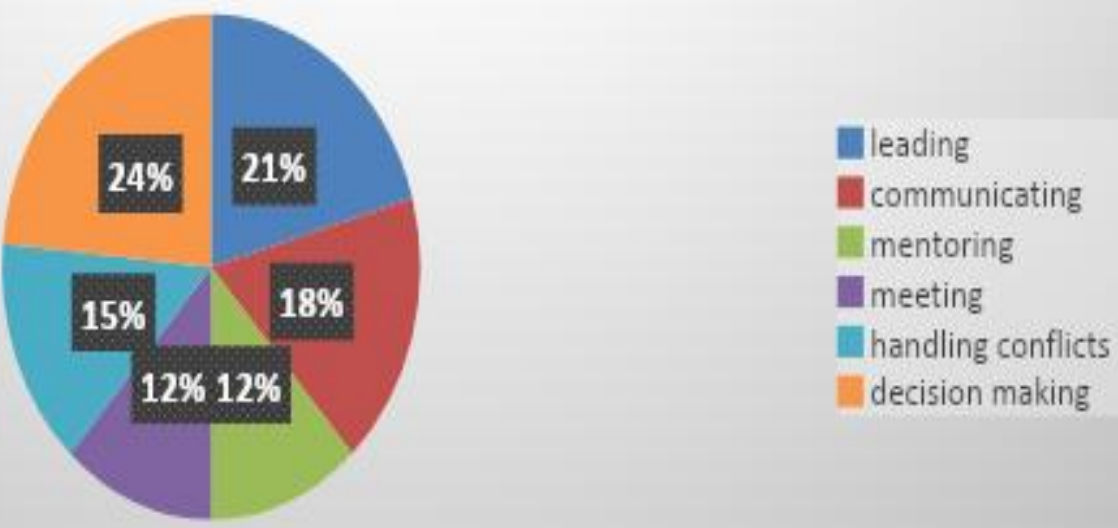

3: Building Rapport to the Employees of Leaders and Managers

Building Rapport to Employees
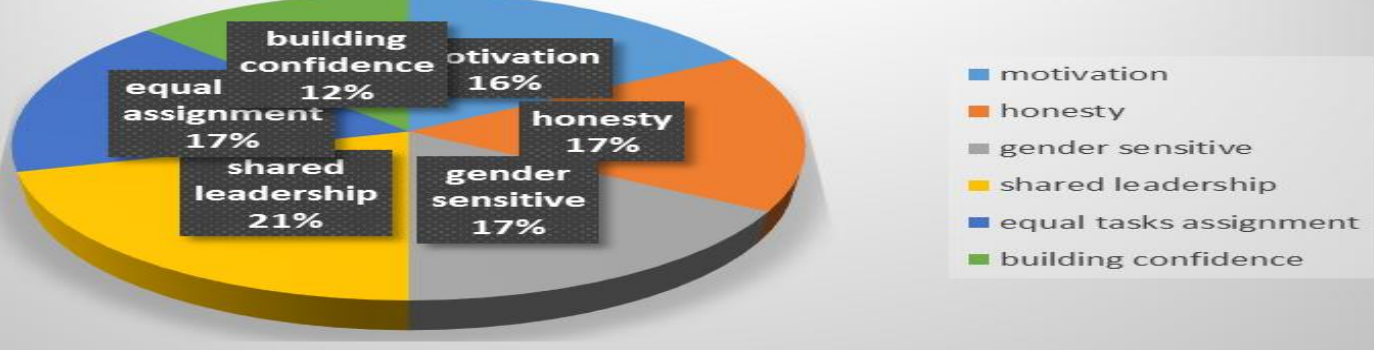
4: Provisions of Managers towards their Responsibilities towards the Employees

\section{Provisions of managers to employees}

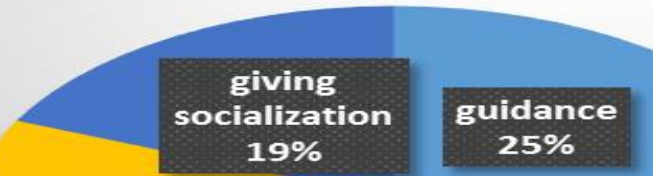

fair treatment $25 \%$

\section{$25 \%$}

\section{for for staff $22 \%$}

-nnual

\section{$9 \%$}

$$
\begin{aligned}
& \text { guidance } \\
& \text { care for staff } \\
& \text { annual recognition } \\
& \text { fair treatment } \\
& \text { giving socialization }
\end{aligned}
$$

\begin{tabular}{|c|c|c|c|c|c|c|c|c|c|c|}
\hline Employee Centricity & $\begin{array}{c}\text { Strongly } \\
\text { Agree }\end{array}$ & $\%$ & Agree & $\%$ & Fair & $\%$ & Disagree & $\%$ & \begin{tabular}{|c|} 
Strongly \\
Disagree
\end{tabular} & $\%$ \\
\hline $\begin{array}{l}\text { 21. I am happy working with my } \\
\text { leaders and managers within the } \\
\text { property. }\end{array}$ & 111 & 64.53 & 33 & 19.19 & 20 & 11.63 & 8 & 4.65 & 0 & 0.00 \\
\hline $\begin{array}{l}\text { 22. My managers treat me well with } \\
\text { great importance especially on my } \\
\text { issues. }\end{array}$ & 103 & 59.88 & 37 & 21.51 & 24 & 13.95 & 4 & 2.33 & 4 & 2.33 \\
\hline $\begin{array}{l}\text { 23. I am satisfied over my } \\
\text { expectations towards my leaders and } \\
\text { managers. }\end{array}$ & 66 & 38.37 & 62 & 36.05 & 16 & 9.30 & 12 & 6.98 & 4 & 2.33 \\
\hline $\begin{array}{l}\text { 24. I feel most valued in the } \\
\text { company as an individual with } \\
\text { respective contribution to the } \\
\text { company. }\end{array}$ & 78 & 45.35 & 49 & 28.49 & 40 & 23.26 & 4 & 2.33 & 0 & 0.00 \\
\hline TOTAL & 358 & 20.81 & 181 & 10.52 & 100 & 58.14 & 28 & 1.63 & 8 & 0.47 \\
\hline
\end{tabular}

\section{Appendix C}

Table 8: Employee Centricity 